new crops to replace imported products, by finding new outlets for established crops, and by better utilization of agricultural waste. Among the new crops are the soya bean, which now covers six million acres. Substances extracted or made from it have manifold uses, and Henry Ford has built a large plant for making plastics out of the meal. Tung oil, valuable for paint and varnish making, is to be derived from extensive plantings of the tung-oil tree; and, also in the Southern States, the quick-growing Southern Pine has been planted over 200 million acres to provide pulp for newsprint and as a raw material for rayon and 'Cellophane'. Among the new outlets for old crops are the use of cotton fabric for reinforcing tarred roads, of inferior cotton and cotton linters for making cellulose derivatives, and of maize for the production of starch, dextrin, corn syrup, dextrose, corn oil and cake. Also under investigation is the utilization of the enormous quantities of straw, cotton stalks, and husks that now run to waste. By promoting agricultural industries on the above lines, it is hoped to put the farmer financially on his feet, and to make him a better customer of the factory.

\section{Total Solar Eclipse of June 8-9.}

THE fact that the expedition of the National Geographic Society and the U.S. Naval Observatory was accompanied by engineers and announcers of the National Broadcasting Company of America has led to the overlooking of the other expeditions organized to observe the recent total solar eclipse (see NATURE of June 12, p. 993). It is good to report that $\mathrm{Mr}$. C. B. Michie, who led an expedition from New Zealand with the aid of the Royal New Zealand Navy also to Canton Island, shared in the good luck in the form of fine weather that came the way of the American party, and secured good photographs of the corona with several very long streamers. Further, it transpires that the Princeton party to Chembote in Peru-and it is hoped the Japanese party there also-had fine weather for the actual eclipse, though as at Canton Island weather prospects were anything but favourable not long before the eclipse. The value of the results obtained by the various parties (and by the party from Princeton, the Franklin Institute and the Cook Observatory on the S.S. Steelmaker near the point of maximum totality) cannot yet be assessed, but in view of the number of experienced observers concerned, one may confidently look forward to results of very considerable importance.

\section{International Peace}

The annual report of the Director of the Division of Intercourse and Education of the Carnegie Endow. ment for International Peace for 1936 pleads for further support for genuine world organization and collective security through an effective world police force. Dr. Murray Butler refers to the existence of a deep-seated popular sentiment against war and to the necessity of this opinion finding expression not merely in emotional outbursts but also in support of definite policies of social, economic and political co-operation and the substitution of judicial process for the threat of force in settling international differences. The advocates of economic nationalism and of neutrality, he said, are making a most insidious attack upon the foundations of prosperity and of peace, for the first involves ultimate national suicide and world-wide disaster and the latter neglect of the highest international obligations. Dr. Butler pointed out that the wars which are most threatening at the present time are between fundamental philosophies of life and of public order, and he referred to the dangers confronting democratic nations.

The Inter-American Conference at Buenos Ayres in December was the brightest feature of the year and received support from public opinion in both American continents. The report refers to co-operation with the International Chamber of Commerce and the adoption in August by the Joint Committee of thirteen practical recommendations for improving commercial relations between nations and dealing with monetary stabilization. Reference is also made to the distribution of literature, to the Leadership Training Conference held in Des Moines, Iowa, to the work of the visiting Carnegie-professors, to the International Relations Clubs, of which 805 have now been formed, as well as to the work of such associated institutions as the American Academy of Political and Social Science, the Institute of Public Affairs at various universities, the Institute of Foreign Affairs, Earlham College, Richmond, Indiana, and the Institute of Pacific Relations. Details of similar work of the Division in Europe are included, indicating the great extent to which the Division utilizes the opportunities afforded by existing organizations for carrying out its educational work.

\section{Archæological Discoveries in Northern Syria}

Sir Leonard Woolley's first report on the current season's work of the British Museum's Archæological Expedition to Northern Syria records important discoveries, which throw fresh light on the Hittite occupation of that area and would seem to confirm references in the Biblical narrative to the relations of the Hittite people and the inhabitants of Palestine in the patriarchal age, which hitherto have been regarded as anachronisms. The expedition, Sir Leonard reports (The Times, June 12), has completed its first season's work in the Amk plain, inland from Antioch. The time available was brief, as excavations begun last year at Mina had to be completed; but an isolated area about twenty yards square in what was believed to be the aristocratic quarter of the city, opened up to a depth of $13 \mathrm{ft}$., has revealed a magnificent building, one of the finest as yet found in northern Syria. This structure is Hittite. It was built of basalt, mud-brick and timber. The approach was from a tile-paved area by way of a flight of basalt steps between platform buttresses, and led through a colonnade into a wide entrance court. The building had been destroyed by a fire; but the chambers adjoining the court were rich in finds of pottery, local and imported, including 